\title{
The constitutional protection of property: The case of Kosovo 1
}

\begin{abstract}
One of the main constitutional legal protections in Kosovo is that applying to property. The Constitution guarantees this and it can therefore be realised at the Constitutional Court. Problems regarding the protection of property have, for many reasons, been a continuous feature of Kosovan institutions and society, notably after 1999. Therefore, this topic, both in the light of the constitutional provisions and in interaction with the standards and interpretations of the European Court of Human Rights, constitutes a highly important one for analysis. This article presents aspects of the requirements for filing complaints over the protection of property, emphasising the position of the European Convention on Human Rights in the Kosovo legal system and the application of Protocol 1 of the Convention. The paper refers mainly to Kosovo, but the academic discourse it generates has general applicability. The Constitutional Court, based on Article 53 of the Constitution, obliges all public authorities to implement the best practice of the European Court in adjudicating the Constitutional guarantees on fundamental rights and freedoms.
\end{abstract}

Keywords: property rights, Kosovo Constitution, European Convention on Human Rights, public interest, material compensation

\section{Introduction}

Constitutional property provisions tend to follow a common structure. Most of these provisions provide that the government may only assume property rights by following procedures set by specific laws; where there is a public use or purpose; and on terms which provide just compensation. These common elements provide the basis for a comparative study of the right to property. Hence, much of the literature centres on several key questions, such as the meaning of property, deprivations of property and due compensation. ${ }^{2}$

1 The author would like to thank Professor Iset Morina, his PhD supervisor, and Professor Qerim Qerimi for their thoughtful suggestions and comments on earlier drafts of this article. A full bibliography is available via the author.

2 Allen, Tom (2011) 'The right to property' in Tom Ginsburg and Rosalind Dixon (Eds.) Comparative Constitutional Law, p. 504. In addition to scholarship based on these interpretive questions, there is a considerable body of writing that takes a more functional approach to the constitutional protection of property. This asks how the right to property affects the scope and impact of laws in specific areas such as, for example, environmental protection (Adler, 2008), or housing and resettlement (Leckie, 2003), or transitional justice and the restitution of prop- 
The Constitution of the Republic of Kosovo (CRK) applies the same logic in which, in Article 46, the right to property is set out as follows:

Article 46 [Protection of Property]

1. The right to own property is guaranteed.

2. Use of property is regulated by law in accordance with the public interest.

3. No one shall be arbitrarily deprived of property. The Republic of Kosovo or a public authority of the Republic of Kosovo may expropriate property if such expropriation is authorized by law, is necessary or appropriate to the achievement of a public purpose or the promotion of the public interest, and is followed by the provision of immediate and adequate compensation to the person or persons whose property has been expropriated.

4. Disputes arising from an act of the Republic of Kosovo or a public authority of the Republic of Kosovo that is alleged to constitute an expropriation shall be settled by a competent court.

5. Intellectual property is protected by law.

Kosovo's acceptance of some of the main international legal acts in the field of human rights and constitutionality, in a unilateral and voluntary manner, ${ }^{3}$ marks a notable progressive development in relation to human rights and, consequently, to property rights.

In addition, Kosovo also adopted another important standard under which human rights and fundamental freedoms are to be interpreted in harmony with the decisions of the European Court of Human Rights (ECtHR). ${ }^{4}$ Based on the reasoning and interpretation of ECtHR decisions, just argumentation may thus be achieved for cases under which the judgments of the Constitutional Court of the Republic of Kosovo (CC) become more persuasive for the community and represent a unification of the comprehension of European standards in terms of human rights and freedoms.

erty (Posner and Vermeule, 2004; Macklem, 2005; Allen, 2007c). It is often assumed that property clauses do have a significant impact on property. Indeed, the inclusion and form of a property clause is often one of the most contested issues in the drafting of new constitutions or constitutional amendments (Alvaro, 1991; Chaskalson, 1995; Choudhry, 2004).

3 Article 22 of CRK [Direct Applicability of International Agreements and Instruments] reads as follows: 'Human rights and fundamental freedoms guaranteed by the following international agreements and instruments are guaranteed by this Constitution, are directly applicable in the Republic of Kosovo and, in the case of conflict, have priority over provisions of laws and other acts of public institutions: (1) Universal Declaration of Human Rights; (2) European Convention for the Protection of Human Rights and Fundamental Freedoms and its Protocols; (3) International Covenant on Civil and Political Rights and its Protocols; (4) Council of Europe Framework Convention for the Protection of National Minorities; (5) Convention on the Elimination of All Forms of Racial Discrimination; (6) Convention on the Elimination of All Forms of Discrimination Against Women; (7) Convention on the Rights of the Child; (8) Convention against Torture and Other Cruel, Inhumane or Degrading Treatment or Punishment.

4 Article 53 of CRK [Interpretation of Human Rights Provisions]: 'Human rights and fundamental freedoms guaranteed by this Constitution shall be interpreted consistent with the court decisions of the European Court of Human Rights.'. 
As far as property rights are concerned, the CRK, along with all constitutions of European Union member states, categorises property rights as part of the fundamental rights and freedoms of the individual and a fundamental constitutional right. ${ }^{5}$ Furthermore, the right to property is treated as one of the 'values' upon which the entire constitutional order of Kosovo is built. ${ }^{6}$ Such a constitutional definition of the right to property and its association with adequate protective measures, as a value, is designed to proclaim it as one of the most basic human rights. Consequently, therefore, the Constitution delegated an exclusive mandate to the legislature regarding the regulation of the right to property and ownership, and its use, conditions and modalities, in accordance with respective legal provisions set by the law. ${ }^{7}$

In Kosovo, in addition to the regular courts, the Constitutional Court of the Republic of Kosovo serves as the mechanism for protection of constitutional rights. ${ }^{8}$

\section{The role of the Constitutional Court in the protection of the right to property}

The most important function of modern constitutional courts is the protection of rights through constitutional justice. ${ }^{9}$ In many states, constitutional courts have become important judicial mechanisms in the protection of the values, freedoms and rights contained in the constitution and act as guarantors of the constitutional protection of citizens' constitutional rights in cases where justice is not served by the ordinary courts. The realisation of the protection of rights, including the right to property, through constitutional judgment implies the protection of such a right by the Constitutional Court of the Republic of Kosovo.

According to the Constitution and legislation in Kosovo, this court is not a part of the regular court system of the Republic of Kosovo. ${ }^{10}$ The Constitutional Court is an independent body with a mandate to protect constitutionality and serves as the final

5 European Union Network of Independent Experts on Fundamental Rights (2006) Commentary on the Charter of Fundamental Rights of the European Union p. 164.

6 Article 7(1) CRK [Values]: 'The constitutional order of the Republic of Kosovo is based on the principles of freedom, peace, democracy, equality, respect for human rights and freedoms and the rule of law, non-discrimination, the right to property, the protection of environment, social justice, pluralism, separation of state powers, and a market economy.'.

7 Article 46(2) CRK: 'Use of property is regulated by law in accordance with the public interest.'.

8 Articles 112-118 CRK and Law No. 03/L-121 on the Constitutional Court of the Republic of Kosovo (Official Gazette No. 46/15, January 2009).

9 Rosenfeld, Michael and András Sajó (2012) Comparative Constitutional Law Oxford: Oxford University Press, p. 823.

10 Article 8(1) of Law No. 03/L-199 on Courts (Official Gazette No. 79/24, August 2010): 'The Court system of the Republic of Kosovo consists of: the Basic Courts, the Court of Appeals and the Supreme Court.' The Supreme Court of Kosovo is the highest judicial authority and has territorial jurisdiction over the entirety of the Republic of Kosovo (Article 103(2) CRK; and Article 21(1) of Law No. 03/L-199). See also Gjylejta Mushkolaj et al. (2014) Komentar i Ligjit për Gjykatën Kushtetuese të Republikës së Kosovës [Commentary on the Law on the Constitutional Court of the Republic of Kosovo] Deutsche Gesellschaft für Internationale Zusammenarbeit, Article 7. 
court of instance in the interpretation of the Constitution. ${ }^{11}$ In its jurisprudence, ${ }^{12}$ the $\mathrm{CC}$ constantly states that it is not the task of the Constitutional Court to deal with errors of fact or law (the legality of the question), which is the preserve of the Supreme Court, except in so far as they may have violated the rights and freedoms (constitutionality) protected by the Constitution. ${ }^{13}$ It is not the CC's responsibility under the Constitution to act as a court of fourth instance in respect to decisions issued by regular courts. The role of the regular courts is to interpret and apply the relevant rules of procedural and substantive law. ${ }^{14}$

In guaranteeing the right to property, as a constitutionally guaranteed right (Article 46), CC does not substitute its legal interpretations for those of the regular courts, but is limited to determining whether the public authorities, or other courts of instance, have properly implemented these rights. ${ }^{15}$

Such a role is already a standard that is unanimously agreed upon in the scientific literature of the theory of constitutional law as conceived all over Europe. ${ }^{16}$ There may be some specific organisational and functional distinctive nuances (such as the case of France), but all have the same purpose. ${ }^{17}$

The importance and function of the $\mathrm{CC}$ in the protection of constitutional rights may exceed the strict limits set by the relevant laws through the development of a high level of intervention/interpretation in their judgments and the establishment of strategic approaches. ${ }^{18}$ This is achieved via a thorough interpretation of the spirit of the Constitution and an assessment of the compatibility and validity of the actions of the state authority and public institutions, including legislation related to the Constitution. ${ }^{19}$ When the issue is raised of the compliance of laws, regulations, decrees and

11 Article 4(6) and 112 of CRK.

12 Hasani, Enver (2016) 'Aspekte komparative të identitetit kushtetues të Kosovës' ['Comparative aspects of the constitutional identity of Kosovo'] XLI(1-4) E Drejta [Law Journal], pp. 7-36 at pp. 18-19. See also Jean Marc Lacourcière (2011) Report on the Jurisprudence of the Constitutional Court of Kosovo on Human and Minority Rights Kosovo Law Centre Publishing, p. 13.

13 Case No. KI60/14, CC, 22 January 2015.

14 See also Case No. KI70/11, CC, 16 December 2011, which is based on the Decision (Case No. 30544/96), Garcia Ruiz v. Spain before the European Court of Human Rights, 21 January 1999.

15 Lacourcière, Jean Marc (2011) op. cit. p. 15; Karen Reid (1998) Practitioner's Guide to the European Convention on Human Rights Sweet and Maxwell, p. 31. See also Decision (Case No. 30544/96), Garcia Ruiz v. Spain before the European Court of Human Rights, 21 January 1999.

16 Ferreres Comella, Víctor (2011) 'The rise of specialized constitutional court' in Tom Ginsburg and Rosalind Dixon (Eds.) Comparative Constitutional Law, p. 265. In this regard, other citations would be: Fromont, 1996; Stone Sweet, 2000; Schwartz, 2000; Olivetti and Groppi, 2003; Sadurski, 2002, 2005; Ginsburg, 2003; Ferreres Comella, 2009.

17 Sweet, Alec Stone (2007) 'The politics of constitutional review in France and Europe' International Journal of Constitutional Law 5(1): 69-92 at pp. 70-71.

18 ibid. at p. 76.

19 Post, Robert C (1990) Theories of Constitutional Interpretation Yale Law School Faculty Series, p. 18. 
statutes with the Constitution, without reference to any specific violations, then we are dealing with the 'abstract control' of constitutionality. In contrast, 'specific control' of constitutionality is what we have when there is a case before the constitutional court referred by an individual complaint based on specific violations. ${ }^{20}$ In the case of specific control, and as opposed to abstract control, the complaints are of a subsidiary nature. ${ }^{21}$ This implies that parties or individuals must exhaust all the legal remedies before the competent authorities and regular courts of instance provided for by the law. ${ }^{22}$

Another important issue is that the CRK is determined as regards the decentralised model of the implementation of constitutional rights and principles. This means that, apart from the Constitutional Court, as the final authority on the interpretation of the Constitution, the regular courts of the judicial system are to take responsibility for the implementation of legal acts. The legal basis for this is the constitutional provision which obliges the courts to adjudicate based on the constitution and the respective laws. ${ }^{23}$ When it comes to the decentralised model of constitutional control and cases raised under it, we must acknowledge that we are dealing with specific constitutional control. ${ }^{24}$

Based on these principles, and given that the right of property primarily has a civil legal character, then it is up to the parties to take care of this right individually. In this sense, material legal property claims and lawsuits concerning its defence are usually individual and are subject only to 'specific constitutional' control by the CC.

20 Rosenfeld and Sajó (2012) op. cit. at pp. 808-810. These methods or models of the implementation of constitutionality are clearly expressed in the Constitution and the legal framework for the Constitutional Court of Kosovo. Thus, the basis for 'abstract control' of constitutionality, according to the CRK, may be found on the occasion of the submission of questions concerning the compliance with the Constitution of laws, decrees of the President and Prime Minister and regulations of the Government, and municipality statutes, as raised by (as authorised parties) the Assembly of Kosovo or a certain group of deputies, the President of the Republic of Kosovo, the Government, the People's Advocate, the courts and Municipalities (Article 113(2) of CRK, in conjunction with Article 29 and further of the Law on the Constitutional Court). Contrastingly, 'specific control' of constitutionality is found in cases referred to the constitutional court by individuals over specific violations by public authorities of their individual rights and freedoms guaranteed by the Constitution (Article 113(7) of CRK, in conjunction with Article 46 of the Law on the Constitutional Court).

21 Patrono, Mario (2000) 'The protection of fundamental rights by Constitutional Courts - A comparative perspective' Victoria University of Wellington Law Review 31(2): 401ff. at p. 412.

22 Article 113(7) of CRK: 'Individuals are authorized to refer violations by public authorities of their individual rights and freedoms guaranteed by the Constitution, but only after exhaustion of all legal remedies provided by law.'.

23 Article 102(3) CRK.

24 Sadurski, Wojciech (1999) Judicial review, separation of powers and democracy: The problem of activist constitutional tribunals in postcommunist Central Europe Studi Politici Numero monografico dedicato all'Europa Centro Orientale, Università di Trieste, pp. 93-120 at pp. 100-102. 


\section{Meaning of property under CRK}

Through the constitutional provision of Article 46 of the CRK, the right to property, as a fundamental subjective legal right, is also a basic right in the body of human rights law, guaranteed by many international acts ${ }^{25}$ as well as the Constitution as the highest legal act. ${ }^{26}$

In this regard, the CRK shows a direction towards co-ordination with all the other rights that are derived from natural law ${ }^{27}$ in which the fundamental rights and principles of justice must exist independently and regardless of place and time, while all specific legal norms should be oriented towards the implementation of this principle. ${ }^{28}$

The right to property under Article 46 of the Constitution, as set out above, follows a concept of property which encompasses not only items and objects but also other rights that may have any economic value or which can obtain any character of property. This concept also accepts the comparative law of some other European countries. ${ }^{29}$ Additionally, this is evidenced in the jurisprudence of the ECtHR, which the CC largely takes into consideration in the course of its adjudication of the cases that come before it. One illustration of this is the case in which the Constitutional Court of Kosovo held that income or pension and disability benefits fell within the scope of the concept of property rights. ${ }^{30}$ Therefore, it can be emphasised that, as far as the material legal aspects are concerned, all the conditions and standards applied by the ECtHR are applied additionally by the $\mathrm{CC}$ without any restriction or distinction. This means that the concept of property rights under the CRK is identical, or should be identical, to the conception of this right as expressed by the European Convention on Human Rights, Article 1 of Protocol 1, as interpreted and adjudicated by the ECtHR.

It is known that the concept of property under Article 1 of Protocol 1 to the Convention includes not only the right to property (movable and immovable property, tangible and intangible property), ${ }^{31}$ but also a variety of contractual and commercial rights - such as rights deriving from shares or clients; intellectual property; patents;

25 Jayawickrama, Nihal (2002) The Judicial Application of Human Rights Law - National, Regional and International Jurisprudence Cambridge University Press, at pp. 908-909.

26 Article 46(1) of CRK: 'The right to own property is guaranteed.'.

27 Wolfe, Christopher (2006) Natural Law Liberalism Cambridge University Press; p. 25; Gottfried Dietze (1995) In Defense of Property University Press of America, pp. 27, 48; Kurtesh Saliu (2001) E drejta kushtetuese [Constitutional Law] University of Prishtinë: Prishtinë, p. 147.

28 Zeiller, Franz (1819) Das natürliche privatrecht [Natural private law] (K.F. Beck), quoted in Peter Bydlinski (2010) Bürgerliches Recht - Allgemeiner Teil [Civil Law - General Part] Springer-Verlag, p. 5.

29 Clarke, Alison and Paul Kohler (2005) Property Law Commentary and Materials Cambridge University Press, p. 26.

30 Constitutional Court of the Republic of Kosovo Case Nos. KI53/11; KI25/12; KI100/12; and KI49/13; 14 October 2011.

31 Drooghenbroeck, Sébastien (2000) "The concept of "possessions" within the meaning of Article 1 of the First Protocol to the European Convention for the Protection of Human 
arbitration decisions; and the right to a pension. This means that all of these might be constituted as assets or possessions under civil law. ${ }^{32}$ Thus, without any theoretical or practical dilemma, it can be argued that the concept and meaning of property under the CRK is, and should be, in line with the interpretations and reasoning of the ECtHR.

\section{Deprivation of property under CRK}

In addition to the protection of individual private interests, and in light of the legal nature of the Constitution as the fundamental legal act of a state, ${ }^{33}$ both public and community property interests are protected as well. In this spirit, Article 46(2) CRK sets out that deprivations of property are permitted only if the respective authority measure is imposed in the public interest and subject to the conditions provided by the law. ${ }^{34}$

In this respect, it is obvious that the Constitution is able to determine, in a balanced way, between 'private interest' and 'public interest', based on the definition of the use of property as regulated by law, in accordance with the public interest. This means that it is within the authority of the legislator to decide and determine the right to property under private law (for example as in the case of the Kosovan Law on property and other real rights), ${ }^{35}$ but also to set the boundaries in order to realise public interests according to public law (such as in the case of expropriation). ${ }^{36}$

The strengthening of the role of the state as a holder of public economic functions and social welfare, especially following the First World War, is considered to have led to this situation. In this sense, states may limit the absolute nature of private property in order to protect the public interest - but always in accordance with the stated interest, and on the basis of the provision of adequate conditions and remedies. ${ }^{37}$ This period represents an important and interesting point of study because 'private property' and 'public interest' (state governance) appear in a parallel manner, confronting an advanced situation in relation to the right to property and the protection of this right. ${ }^{38}$ At this stage, the right to property cannot be subject to absolute exercise and the control of the individual; however, it can be made subject to the

Rights and Fundamental Freedoms', The European Legal Forum (E) 7-2000/01, pp. 437-444, at p. 438.

32 Grabenwarter, Christoph (2014) European Convention on Human Rights - Commentary Verlag C.H. Beck, p. 367.

33 Saliu (2001) op. cit. p. 45.

34 Article 46(3) CRK.

35 Law No. 03/L-154 on Property and Other Real Rights Official Gazette No. 57/04, August 2009.

36 Law No. 03/L-139 on Expropriation of Immovable Property Official Gazette No. 52/08, May 2009.

37 Alexander, Gregory S (2003) Property as a Fundamental Constitutional Right? The German Example Cornell Law Faculty Paper 4, pp. 1-62 at pp. 11-13.

38 Benson, Bruce L (2010) Property Rights - Eminent Domain and Regulatory Takings ReExamined Palgrave Macmillan, p. 1. 
interest of the community, in the way that these have been established, by exploiting resources in the name of development, and by regulating the general social order. ${ }^{39}$

Nevertheless, it is still claimed, or assumed, that the right to property is a guaranteed natural right, in harmony with legitimate state processes. ${ }^{40}$ The historical and the current comprehension of the guarantee of property encompasses an understanding of a fundamental right that is closely connected to individual freedom, because the private function of the right to property has its influence on the normal enjoyment of the individual's freedoms and rights. ${ }^{41}$ After all, it can be said that it is difficult to live freely without property. ${ }^{42}$

Such limitations may only be imposed to the extent necessary for the achievement of the purpose for which those restrictions are permitted. Public institutions are obliged to pay attention to the essence of the limited right, the importance of the restriction having a purpose, the nature and scope of the restriction, the relationship between the limitation and the purpose intended to be achieved. Furthermore, they must consider whether that purpose might be achieved with as low a level of restriction as possible. ${ }^{43}$ In the case of conflict (i.e. a dispute) between these concepts (the right and the restriction), the role of the constitution steps forward - more precisely the Constitutional Court, as the final authority in the interpretation of the constitution - to verify whether one or another right has been violated, and whether the conditions set by the Constitution and the relevant laws have been respected.

In this regard, the German Constitutional Court has also interpreted that the spirit of the Constitution, in the sense of private property respecting the principle of the social state, permits the regulation of property rights as a means of balancing the requirements of society with individual interests. ${ }^{44}$ The same approach is also present in the comparative rights present in some surrounding states. ${ }^{45}$ This principle, or this approach, may not be explicitly present in some constitutions (as is the case in the

39 Davies, Margaret (2007) Property - Meanings, histories, theories Routledge-Cavendish Publishing, p. 2.

40 Hepburn, Samantha (2001) Principles of Property Law Cavendish Publishing, p. 6.

41 BVerfG 58, 225 (300), Constitutional Court of Germany.

42 Schwartz, Herman (1987) 'Property Rights and the Constitution' University Law Review 37(9): 9-39 at p. 35.

43 Article 55 CRK.

44 BVerfG 25, 112 Niedersächsisches Gesetz, Summary of Decisions (Konrad-AdenauerStiftung 2010) p. 425.

45 It can be concluded from some of the decisions that the principle of justice requires that not only private interests, but also those of other members of society, as well as the public interest as a whole, be taken into consideration, and that principle should therefore correspond to the proportionality principle. See the Decision of the Constitutional Court of Albania No. V-30/2005 which, in this respect, is based on the Latvian Constitutional Court Decision No. 2002-12-01; the Decision of the Constitutional Court of the Czech Republic No. P1.US 1/98; and the decision of the German Constitutional Court BverfG 84, 91 (121, 130) (Gerechtigkeit und Socialstaatlichkeit). 
USA); ${ }^{46}$ nevertheless, it is present in a dispersed manner in court decisions and jurisprudence. ${ }^{47}$

The basic law defining the conditions in Kosovo for the acquisition of private property by public authorities in the public interest is the Law on the Expropriation of Immovable Property. ${ }^{48}$ According to this law, the essential conditions for a just expropriation are three-fold:

- the existence of a public interest

- that public purpose must be legitimate in the eyes of the law

- compensation must be paid for the expropriated property. ${ }^{49}$

The first condition - the concept of a 'public or general interest' - may include a wide range of meanings and interpretations. ${ }^{50}$ According to the interpretation provided by the European Convention on Human Rights, the public interest in particular relates to the interest of a community, which may be inter-related with various issues such as housing, shelter and conditions for the establishment and development of social welfare which are given primary importance and which play a central role in the economic policies of states. ${ }^{51}$ In this sense, the Law on the Expropriation of Immovable Property defines particular business activities such as:

- the implementation of an urban and/or spatial plan

- the construction or extension of a building or facility to be used for public functions

- the construction, expansion or establishment of infrastructure and/or technical facilities

- the construction of public roads, railways, airports and public buildings

- the construction of various public amenities, such as landfill sites, public cemeteries, public parks, etc.

46 Underkuffler, Laura S (2007) 'Property as Constitutional Myth: Utilities and Dangers' Cornell Law Review 92: 1239-1254, at pp. 1241-1242.

47 Commentary Fourteenth Amendment - Rights Guaranteed Privileges and Immunities of Citizenship, Due Process and Equal Protection United States Government Printing Office, p. 1628. See also Walter F. Murphy and Joseph Tanenhaus (1977) Comparative Constitutional Law: Cases and Commentaries Martin's Press, p. 15; Thomas W. Merrill and Henry E. Smith (2010) The Oxford Introductions to US Law: Property Oxford, p. 18.

48 Law No. 03/L-139 on the Expropriation of Immovable Property Official Gazette No. 52/08, May 2009.

49 Article 4 of Law No. 03/L-139. In the constitutional aspect, these conditions have also been confirmed by the Constitutional Court of Kosovo that they are in accordance with the Constitution of the Republic of Kosovo. See Case No. KO4/11, CC, 1 March 2012, paragraph 39,40 of judgment.

50 Grabenwarter (2014) op. cit. at p. 376.

51 Saliba and others v. Malta, App. No. 20287/10, November 22 2011, available at: http://hud oc.echr.coe.int/eng? $\mathrm{i}=001-107508$. According to paragraph 60 of this judgment, the notion of 'public' or 'general' interest is necessarily extensive. In particular, it regarded that spheres such as housing, which modern societies consider a prime social need and which plays a central role in welfare and economic policies, may often call for some form of regulation by the state. 
The second condition - that the public purpose must be a legally legitimate one implies that the general or public interest must be defined or envisaged as such in accordance with any legal act or law. Regarding what is meant by 'foreseen by the law' under the European Convention on Human Rights, the ECtHR has interpreted this and given clear direction. ${ }^{52}$ In connection with this, the Kosovo Law on the Expropriation of Immovable Property determines that the public benefit from the expropriation must be greater than the interests that will be adversely affected by it; and that the immovable property which is the subject of the attempt at expropriation is not being used for discriminatory purposes. ${ }^{53}$

The focus on a determination by the law of the purpose behind any interference with property rights (the principle of legality) is of primary importance since, if the ECtHR finds that interference with the property right was not in accordance with the law, then it does not review any other elements, such as the purpose of the state intervention or the issue of proportionality or compensation. In this case, ECtHR focuses on the breach of the principle of legality, which automatically leads to a violation of Article 1 of Protocol 1 of ECHR. ${ }^{54}$ This can conform to evidence as regards ECHR jurisprudence. ${ }^{55}$

The third condition - the need to provide adequate compensation for expropriated property - should be assessed on the basis of the market value of the property, determined in accordance with particular criteria and legal acts. Compensation may include both the value of the expropriated immovable property, including auxiliary elements, and the gains that it produces; as well as compensation for eventual damages that may be evidenced or those which are incurred as a result of the expropriation. ${ }^{56}$

52 Sunday Times v. United Kingdom, App. No. 6538/74, April 26 1979, available at: http://hu doc.echr.coe.int/eng? $i=001-57584$. In the Court's opinion, the following are two of the requirements that flow from the expression 'prescribed by the law'. Firstly, the law must be adequately accessible: the citizen must be able to have an indication that is adequate in the circumstances of the legal rules applicable to a given case. Secondly, a norm cannot be regarded as a 'law' unless it is formulated with sufficient precision to enable the citizen to regulate his or her conduct: he or she must be able - if need be with appropriate advice - to foresee, to a degree that is reasonable in the circumstances, the consequences which a given action may entail. See para. 49.

53 Article 4 of Law No. 03/L-139.

54 Harris, David, Michael O'Boyle, Ed Bates, Carla Buckley, Paul Harvey, Michelle Lafferty, Peter Cumper, Yutaka Arai, Heather Green (2014) Law of the European Convention on Human Rights Oxford University Press, p. 878.

55 Iatridis v. Greece, App. No. 31107/96, March 25 1999, available at: http://hudoc.echr.coe.i $\mathrm{nt} / \mathrm{eng}$ ? $\mathrm{i}=001-58227$. In this case, the Court reiterates that the first and most important requirement of Article 1 of Protocol No. 1 is that any interference by a public authority with the peaceful enjoyment of possessions should be lawful. It follows that the issue of whether a fair balance has been struck between the demands of the general interest of the community and the requirements of the protection of the individual's fundamental rights becomes relevant only once it has been established that the interference in question satisfied the requirement of lawfulness and was not arbitrary. See para 58.

Article 15 of Law No. 03/L-139. 
With regard to the protection of property rights, it is the monetary aspect which prevails in the sense of compensation. Stemming from the right to property, this is because it concerns a material interest, with the court ultimately caring about making an adequate financial assessment of the damage resulting from the alleged violation by the parties. ${ }^{57}$ The ECtHR takes the same interpretation in cases that come before it, stating that, from the perspective of the Convention, property is considered a material product which can be assessed and compensated in the context of monetary terms. ${ }^{58}$

\section{Procedural requirements for constitutional protection under CRK}

In general, the protection of rights and freedoms before the $\mathrm{CC}$, including the protection of property, may be sought upon the fulfilment of certain presumptions or basic requirements of a procedural nature. It is on these that the admissibility of a complaint regarding the protection of constitutional rights depends.

The first requirement to be fulfilled is that the parties must be authorised to bring a complaint under the Constitution and they must have exhausted all legal remedies before the regular courts and competent authorities established by the law.

The second requirement is that the rights alleged to have been violated must derive from a decision or legal action by a public authority.

The third requirement is to specify the complaint, in which the party should clarify exactly what rights and freedoms he/she claims were violated and the specific action which the public authority had undertaken.

Finally, the fourth requirement to be fulfilled is the prescribed time limit, which is four months commencing from the day the applicant is served with the decision which bears legal consequences for that party; or, in other cases, the time limit begins to run on the day the decision or act is publicly announced. If the complaint is filed against a certain law, then the time limit starts to run from the day the law entered into force.

Exceptionally, a request for restitutio in integrum (return to the previous state) may be granted where the $\mathrm{CC}$ finds that a claimant has proven that they were not able to file a complaint with the $\mathrm{CC}$ within the prescribed time limit through no fault of their own. The claimant must request a return to the previous state within fifteen days from the moment a claimant removed any obstacles or became aware of a decision and with an objective deadline in mind of one year from the day the deadline in question for filing a claim before the CC expired. ${ }^{59}$

57 Ichim, Octavian (2015) Just satisfaction under the European Convention on Human Rights Cambridge University Press, p. 134.

58 Takis Demopoulos and others v. Turkey, App. No. 46113/99, 3843/02, 13751/02, 13466/03, 10200/04, 14163/04, 19993/04, 21819/04, March 1 2010, available at: http://hudoc.echr.co e.int/eng?i=001-97649. In the Court's opinion, from a Convention perspective, property is a material commodity which can be valued and compensated for in monetary terms. See para. 115.

59 Article 113(7) of CRK, in conjunction with Articles 46-50 of Law No. 03/L-121. 
Those with natural and legal forms of identity, in so far as the constitutionally guaranteed rights and freedoms may be applicable to them, ${ }^{60}$ are entitled to bring a case before the $\mathrm{CC}$, including those with a legal public law identity. ${ }^{61}$

Argumentum ad contrario implies that the CC does not undertake ex officio actions but parties are required to initiate a procedure themselves. A claimant must always indicate what decision, legal action, breach or omission was made by the public authority which is alleged to have committed the violation. This means that, even in proceedings before the $\mathrm{CC}$, there is a need for legitimatio ad causam. Furthermore, the party must personally indicate which right was directly violated, which means that it requires argumentation of the legal interests behind the alleged violation, the term used in law, because so-called actio popularis is not applicable. The practice of the $\mathrm{CC}$ proves that some claims filed before the Court have been found inadmissible because they had the nature of actio popularis. ${ }^{62}$

For comparative purposes, one can state that the initiation of ex officio proceedings by constitutional courts and applications of actio popularis in the constitutions of other countries is very rare. ${ }^{63}$

Last but not least, we should mention here the issue of the jurisdiction of the Constitution and the Constitutional Court in relation to ratione materiae, ratione personae or ratione temporis. Apart from some of the main criteria being encountered in one way or another in the Constitution and the $\mathrm{CC}$, it is important to note that, more specifically, such criteria are also foreseen in the CC's Rules of Procedure, which represents the last part of the legislation and the Regulation on which CC decisions are referenced and based. ${ }^{64}$ Additionally, this Regulation is in line with the admissibility criteria resulting from Article 35 of the Convention and the practice followed by the ECtHR. The CC may consider a referral if this has been filed by an authorised party; or where all effective remedies that are available under the law against the judgment or the decision being challenged have been exhausted; or where the referral is filed within four months from the date on which the decision on the last effective remedy was served on the applicant; or where the referral is prima facie justified or, at least, not manifestly ill-founded.

60 Article 21(4) of CRK. See also the legal practice of CC in Case No. KI 41/09, 27 January 2010.

61 Case No. K.I 25/10, CC, 4 February 2010.

62 Case No. K.I 09/09, CC, 19 November 2009.

63 Mavcic, Arne (2009) Access to The Court - The applicant in Constitutional Jurisdiction European Commission for Democracy through Law - Venice Commission, 6 November, p. 2. Of the countries in the region, one can mention the case of Hungary which, until the changes of 2011, had envisaged the possibility of actio popularis. See also Bernadette Somody and Beatrix Vissy (2011) Citizen's role in constitutional adjudication in Hungary: From Actio Popularis to Constitutional Complaint ELTE University Press, p. 1.

64 Article 115 of CRK: 'The Constitutional Court shall determine its internal organization, rules of procedure, decision-making processes and other organizational issues pursuant to law. The Constitutional Court shall publish an annual report.' Article 2(2) of Law No. 03/ L-121 provides likewise that: 'The Constitutional Court shall determine its internal organization, rules of procedure, decision-making processes and other organizational issues pursuant to law.'. 
The CC declares a referral as manifestly ill-founded when this is not prima facie justified, where the presented facts do not in any way justify the allegation of a violation of constitutional rights or where the applicant is not able sufficiently to substantiate his or her claim. A referral may also be deemed inadmissible in any of the following cases:

- the CC does not have jurisdiction in the matter

- the referral is made anonymously

- referral is held to be an abuse of the right of petition

- the CC has already issued a decision on the matter concerned and the referral does not provide sufficient grounds for a new decision

- the referral is incompatible with the CRK on either a ratione materiae, ratione personae or ratione temporis basis. ${ }^{65}$

It should also be noted that the $\mathrm{CC}$ has an ultra petitium mandate and may therefore extend a trial in abstracto so as to review the constitutionality of a particular issue that has direct relevance to the alleged violation caused in an individual case which is being adjudicated. ${ }^{66}$

\section{Conclusion}

Based on the foregoing analysis, there are three fundamental conclusions that can be emphasised.

First, we consider that, based on the Constitution of the Republic of Kosovo, property is treated as a fundamental constitutional right of a person and as one of Kosovo's constitutional values. This implies that property, in constitutional terms, goes beyond the authorisations which derive from the legal provisions under private law which are institutionally below the level of the Constitution. Consequently, the scope of the right to property cannot be determined under the rules of private law.

Secondly, each property or ownership interest is treated within the scope of the concept of property under the Constitution.

Thirdly, in terms of ensuring a balance between the interests of individuals and the public interest, the right to property is not to be denied or taken away arbitrarily by anyone except under the conditions prescribed by the law.

65 Rule 36 of the Rules of Procedure of the Constitutional Court of the Republic of Kosovo, 1 March 2015, available at: http://gjk-ks.org/en/the-constitutional-court/legal-base/rules-of-pr ocedure/ [last accessed 30 August 2018]. 
